\title{
Analysis on Our Country's Foreign Trade of Agricultural Products
}

\author{
Yan Li \\ Southwest Minzu University, Chengdu, China \\ Email: 2589011901@qq.com
}

How to cite this paper: Li, Y. (2021) Analysis on Our Country's Foreign Trade of Agricultural Products. Open Access Library Journal, 8: e7582.

https://doi.org/10.4236/oalib.1107582

Received: May 25, 2021

Accepted: June 21, 2021

Published: June 24, 2021

Copyright () 2021 by author(s) and Open Access Library Inc.

This work is licensed under the Creative Commons Attribution International License (CC BY 4.0).

http://creativecommons.org/licenses/by/4.0/

\begin{abstract}
With the development of economic globalization and the international division of labor system, countries are increasingly closely linked economically in various fields, forming a pattern of interdependence. This also makes the economic and trade barriers of various countries gradually reduced, providing a good opportunity for China's agricultural products to the world. China is an agricultural country in the true sense, with the output of most agricultural products ranking first in the world. Due to China's large population, the arable land per capita is limited due to the small amount of arable land available for food cultivation. In addition, China's agricultural economy in the field of science and technology investment is less, agricultural mechanization, organization, automation degree is low. Therefore, the self-sufficiency of agricultural products is more difficult, the degree of external dependence is more serious. How to give full play to the advantages of the import and export of agricultural products in the context of international environment and solve the problems that always exist in the import and export of agricultural products in China is of practical significance for people to realize the needs of a better life and alleviate the main social contradictions in China. This paper points out the importance of international trade in agricultural products to the life of Chinese people and the adjustment of industrial structure based on the background of international trade in agricultural products by reading the researches of previous scholars in related fields. Then through the study of domestic and foreign related literature, this paper discusses the three stages of the development of China's agricultural products foreign trade. Secondly, it analyzes the current situation of foreign trade of agricultural products and its export competitive advantages and disadvantages from the aspects of the structure of foreign trade of agricultural products and participating countries. Finally, a series of problems in the export of agricultural products in our country are put forward the corresponding countermeasures.
\end{abstract}




\section{Subject Areas}

International Economics

\section{Keywords}

Economic Globalization, Foreign Trade of Agricultural Products, Current Situation, Solution

\section{Introduction}

Since ancient times, our country has been a real agricultural country. Agriculture is the basic industry of China's national economy. At the Fifth Plenary session of the 16th CPC Central Committee in 2005, the problems of agriculture, rural areas, farmers were formally put forward, which has become a particularly important issue in our country at present. In 1978, Xiaogang Village, Fengyang County, Anhui Province opened the prelude of rural reform with big package dry. In the past 40 years of reform and opening up, China's agricultural field has made breakthrough achievements.

At the 19th CPC National Congress meeting of the Party, General Secretary Xi Jinping put forward major decision-making arrangements for the strategy of rural revitalization, which has become a strategic and overall historical task of building a well-off society in an all-round way and building a socialist modern country. In rural land distribution, the three rights of ownership, contract and management are divided. In recent years, the Central Committee's No. 1 document has placed great emphasis on promoting the export trade of Chinese agricultural products, and the Ministry of Commerce has also issued the 11th FiveYear Plan for the Export of Agricultural products, which lists a series of non-tariff measures as the biggest barrier to the export of agricultural products. Agriculture is the basic industry of our country and has a very important influence on the economic development of our country, especially for a large agricultural country with a large population and an extremely large agricultural population. The development of foreign import and export trade of agricultural products is very important.

Over the past 40 years, farmers have really felt the changes brought by reform and opening up to the agricultural economy. Due to industrialization, the pace of urban urbanization is speeding up, township enterprises are growing day by day, and rural surplus labor force is transferred to urban and rural non-agricultural industries for employment. So that can be engaged in agricultural work of young labor force loss. But even in the case of seasonal and structural shortages of rural labor, agricultural production and farmers' income have increased significantly. At the same time, the amount of grain import and export trade has been rising, and the living standards of farmers have been greatly improved, taking an im- 
portant step towards achieving accurate poverty eradication.

With the help of the background of the times and the policy support of the state government, the people of the whole country are industrious and pragmatic, work hard, constantly practice the spirit of reform and opening up, actively promote the import and export trade of agricultural products, promote rural modernization, and expand the scale of grain exports.

With the vigorous development of reform and opening up and economic globalization, all regions develop local characteristic agriculture according to local conditions, and export agricultural products with competitive advantages will inevitably have corresponding problems at the same time. This paper puts forward some reasonable solutions to the present situation of the total import and export trade of agricultural products in China and the related problems. It is hoped that the development of local and even national agricultural economy and China's grain export trade will be promoted by promoting the total export trade of related agricultural products.

However, the previous articles mainly analyzed the current situation of China's foreign trade of agricultural products, and few scholars analyzed the reasons for the existing problems. This paper mainly from the internal and external reasons in the import and export trade of agricultural products, to explore the ways to solve the long-term problems in foreign trade of agricultural products.

\section{Review of Domestic Literature}

Since the import and export trade of agricultural products in China developed in the period of reform and opening up, there are many related documents at home and abroad to systematically introduce it. This paper refers to several articles of domestic authors for further study.

Chen Zhigang (2011) [1] said, Under the background of economic globalization and international free trade, various countries are increasing traditional trade barriers such as tariff reduction, but then there are various non-tariff trade barriers, SPS measures are one of the typical representatives. For different standards, SPS classification is different. The general meaning refers to a set of rules specially designed to protect the health of human beings, animals and plants. As a result, non-tariff trade barriers represented by SPS measures have become one of the main obstacles affecting agricultural trade. Because different countries have different food safety standards, the requirements for SPS measures vary from country to country. By means of quantitative economic model and typical case analysis, the author makes relevant analysis on the advantages and disadvantages of the measures in China's agricultural products foreign trade through theoretical and empirical research, and puts forward some countermeasures and suggestions for how to deal with different kinds of SPS measures in China's agricultural products export.

Liu Xiaoyun (2006) [2] wrote in "the impact of agricultural trade liberalization on rural poverty in China” that while China's economy is developing rapidly, 
China's trade, including agricultural products, is also developing rapidly. Whether the rural population with agricultural products as the main source of income can seize this opportunity to narrow the gap between the rich and the poor and the urban population is an urgent issue for us to consider. How to grasp the background of economic and trade liberalization, introduce relevant trade policies, actively expand the export amount of Chinese agricultural products, and increase the income of rural population? But as the world economy becomes more open, will trade liberalization in turn further exacerbate poverty among the rural poor? Obviously, this cannot be avoided under the social law of efficiency first and fairness. In the twenty-first century, poverty remains a major global problem. There are still about 26.1 million poor people in China.

Wu Haipeng (2016) [3] mentioned in "the influence of American grain strategy on the development of China's agricultural industry" that the United States, by virtue of its strong agricultural strength, will adopt a series of different trade policies in different historical stages to safeguard its own national political, economic and cultural interests. It includes advocating the food culture habits of various countries to close to the United States, and the related trade of agricultural products is centered on the United States. Some of its grain strategies will inevitably affect the related development of agriculture in China, and the recent Sino-US trade war has also affected the demand structure of Chinese residents for agricultural products to some extent.

Chen Gang (2018) [4] pointed out in a relevant article that the current export volume of China's agricultural products shows a trend of growth, but the trade deficit is still expanding, and the export structure is unreasonable, mainly concentrated in labor-intensive products Chen Jiaying (2019) [5] through analysis, our country agricultural product foreign trade mainly by the green barrier, comparative advantage, product added value and other related factors So to solve the long existing in current agricultural products trade deficit will be from dealing with green trade barriers, to strengthen the comparative advantage of agricultural products and value-added, pay attention to product brand effect, fundamentally solve the problem According to Hu Dening (2020) [6], in the context of the long-term deficit in China's foreign trade of agricultural products, One Belt And One Road strategy proposed can expand agricultural products to a certain extent, alleviate the degree of trade deficit, breakthroughs in agricultural exports Yang Yang (2021) [7] in the article pointed out that China's foreign trade imports of agricultural products have a certain degree of narrowing, shows that China's foreign dependence of grain decreases, but the gap is still large and showed a trend of growth as a whole

Foreign direct investment is also playing a significant role in China's agricultural industrial agglomeration and structural changes. China must rely on its own agricultural development advantages to meet the food demand of its residents in order to reduce its dependence on imported grain from the United States. 


\section{Development of China's Agricultural Trade}

China's agricultural export foreign trade in the period of reform and opening up can develop rapidly. Since the founding of the people's Republic of China until the reform and opening up, the state has implemented a strict planned economy, foreign trade is monopolized by state-owned foreign trade enterprises, and the scale of import and export is relatively small. In 1978, Deng Xiaoping put forward the great strategic practice plan of reform and opening up and socialist modernization construction at the third Plenary session of the 11th CPC Central Committee. Since then, China has entered a new great period of reform and opening up. In the past 40 years, the foreign trade of agricultural products has developed rapidly, from the beginning of reform and opening up (1979-1993) to the following (1994-2001), and then to (2002 to present) a total of three stages of development.

\subsection{Rapid Growth Phase: 1979-1993}

During this period, the increase of the total amount of agricultural products' foreign trade in China is relatively large, but the proportion of the total amount of commodity trade shows a downward trend. In 1979, China's total foreign trade in agricultural products was US $\$ 11.37$ billion, and by 1993 , its trade volume had grown to US $\$ 20.5$ billion. The main data show that the amount of foreign trade export of agricultural products in China is on the rise in this stage, but the fluctuation of import amount is unstable, but its overall trend is on the rise. At the beginning of reform and opening up, due to the adjustment of agricultural industrial structure, the total import and export trade of agricultural products gradually changed from deficit to surplus. The difference fluctuated.

\subsection{Volatility in 1994-2001}

At this stage, although the amount of agricultural trade hovering fluctuations, but has been in a state of surplus. In foreign trade, the export amount of agricultural products has been showing a stable trend, but its import amount fluctuates sharply. Therefore, China's agricultural trade balance will also fluctuate with the fluctuation of import volume. China's export market concentration is high, import market is relatively single. Asia is China's main export-oriented agricultural products, its export share of about $70 \%$. But in the late 1990s, affected by the Asian financial crisis, the share of agricultural exports to Asia showed a downward trend. With the continuous improvement of economic and trade relations between China and the United States, the United States has become the main source of grain imports in China, and the import market of agricultural products has gradually diversified.

\subsection{2-Present Comprehensive Development Phase}

At this stage, the agricultural trade deficit increased year after year, but its total trade showed a growing trend. However, because our country is a country with 
abundant labor force, the export of agricultural products in China is still mainly labor-intensive products. The export of livestock products and aquatic products accounts for about $65 \%$. China has always been the largest exporter of aquatic products. The proportion of exports of fruits, vegetables and livestock products has decreased. The import dependence on grain, oil, cotton and sugar and other bulk agricultural products is relatively high, especially the import quantity of soybean increases rapidly. In 2017, soybean imports accounted for more than $85 \%$ of the total demand for soybean by domestic residents. At the same time, China's agricultural trade export market concentration decreased, import market concentration increased. Due to the idea of Belt and Road initiative, China's export proportion to the countries along the route and the export tendency of some emerging market countries such as Mexico and Turkey have increased; the import sources are mainly concentrated in the United States, Brazil, Canada and other countries, and the import market is relatively single.

\section{Current Situation of China's Agricultural Trade}

Since our accession to the World Trade Organization, The total scale of agricultural product trade shows the trend of increasing year by year. The data show, January-December 2017, China's imports and exports of agricultural products amounted to $\$ 1998.2$ billion, The year-on-year increase was 9.1. December 2017, China's imports and exports of agricultural products amounted to $\$ 19.79$ billion, An increase of $4.2 \%$, The amount of imports and exports increased by $6.0 \%$ over the same period last year. In 2017, China's total export of agricultural products was 75.14 billion yuan, Year-on-year growth of 3.5 per cent; Total imports amounted to $\$ 124.68$ billion, The year-on-year increase was 12.7. Apparently, The volume of imports and exports of agricultural products has increased to a certain extent, However, the volume of exports increased much less than the volume of imports. It shows that China's foreign trade in agricultural products is still not dominant, The deficit is relatively large, Strong dependence on foreign related agricultural products, The advantage of agricultural product export in international position is not obvious. Experts predict, Over the next few years, Although our country agricultural product deficit scale has the downward trend, The average decrease was 51.5 per cent; But in the medium to long term, Due to the lack of sustainable industrial chain in the international trade of agricultural products in China, The scale of its agricultural trade deficit will still show a growing trend.

\subsection{The Total Volume of Foreign Trade Is Larger but the Volume of Exports Is Smaller}

China is a large country with a large population, which makes the production and consumption of food and agricultural products relatively large, and a large number of surplus agricultural products must be exported to foreign countries. Thus, China also occupies a place in the world's major agricultural export coun- 
tries. The agricultural products exported from China show a rising trend in the proportion of all agricultural products exported from the world, and also contribute to the world trade pattern. The data show that China currently ranks fifth in global agricultural products, In the global agricultural exports ranked fourth. At present, China's traditional agriculture is undergoing various tests brought about by changes in the market environment, So that China's international competitiveness of agricultural products in the world agricultural products do not dominate. 2001, Since our accession to the World Trade Organization, The total scale of agricultural trade has been rising over time. The data show, 2001, China's total import and export of agricultural products is $\$ 27.9$ billion, But in 2016, The amount of our agricultural trade has grown to $\$ 19,972$ billion, At this stage, Total trade increased by 6.9 times. Among them, Agricultural imports have increased particularly rapidly. The average growth rate is 19.2 percent. It shows that China's dependence on foreign agricultural products is still very serious. On the other hand, the average growth rate of exports was only 12.4. Due to the gradual reduction of import tariff level of agricultural products in China, Foreign imports of low-priced agricultural products, the influence of domestic agricultural production cost increase and other factors, for the first time in 2004, China's agricultural trade deficit, The deficit was $\$ 4.64$ billion. In recent years, although the deficit of agricultural products in China is decreasing year by year, The average decline was 51.5 per cent, But in the medium to long term, China's agricultural trade deficit is still expanding.

\subsection{Concentration of Foreign Trade in Agricultural Products with a Single Market Orientation}

China is in the primary stage of socialism, and the contradiction between the growing needs of the people for a better life and the backward social production is the main contradiction in our country. Although our government has issued a series of relevant policies to support agriculture, rural areas and farmers, in order to improve the current lagging situation of agricultural development, so as to promote the coordinated development of the first, second and third industries and increase the gross domestic product. However, compared with the western agricultural developed countries, China's emphasis on foreign agricultural trade policy is still not enough, which leads to the rising speed of agricultural production level and the development speed of China's social and economic level. Thus affecting the international competitiveness of China's agricultural products. Although there are more than 200 agricultural export countries or regions in China, the main market of foreign trade is relatively concentrated and stable (Japan is China's largest grain export market oriented). In recent years, China's agricultural exports have been mainly concentrated in Asia, Europe and North America, such as Japan, South Korea and European Union countries. Because China's agricultural exports are more market-oriented, it is not conducive to the healthy and coordinated development of China's agricultural export trade countries. In 
recent years, according to the relevant investigation, it is found that the proportion of exports to countries, such as Korea and Japan, is decreasing. Because the export market countries are too concentrated and the structure is uneven, the security of agricultural products trade in China is unstable.

\subsection{The Types of Foreign Trade Products Are Single, Mainly Raw Agricultural Products, with Low Added Value}

The terrain and climate conditions of our country are complex and diverse, so the dominant varieties of agricultural products are abundant, but at present, our country mainly concentrates on the export of raw agricultural products and rough processed products, such as vegetables and aquatic products, and the structure of export products is single. This is determined by Heckscher-Ohlin resource endowment theory. China has a great advantage in population quantity, labor resources are in a favorable position compared with other countries, so it will export a large number of labor-intensive products. In turn, China's technical equipment is relatively backward, for some finishing, deep processing of agricultural products mainly imported.

\section{Analysis on the Competitiveness of China's Agricultural Trade}

In recent years, due to the increase of government support for agriculture and the good terrain and geographical environment of our country, the trade volume of agricultural products in China has steadily increased. But at the same time, the foreign trade deficit of agricultural products is increasing year by year because of the increasing non-tariff trade barriers and insufficient market information. And there are relevant data that the trade deficit of agricultural products in China will be further expanded.

\subsection{Competitive Advantage of China's Agricultural Trade}

\subsubsection{Vast Area, Diverse Terrain, Rich Product Types}

China is a country with about 9.6 million square kilometers of land area, ranking third in the world. China's agricultural planting industry relies on the vast cultivated land area to prepare the premise and possibility for its healthy development. The increase in cultivated land area will inevitably increase the total output of grain, thus making it possible to have more total grain available for export trade on the basis of meeting the basic food needs of domestic residents. Ease the huge trade deficit brought to our country by other industries whose competitive advantage is not obvious. In addition, China's complex geological structure, complex and diverse types of terrain has laid a good foundation for the development of a variety of agricultural management types. Different types of agricultural products are conducive to further coordinating the specific gravity relationship of the types of agricultural products exported to China. As we all know, international trade in agricultural products needs a solid agricultural foundation. 
Compared with other countries in the world, China is a large agricultural country, with a long history of agricultural planting and a variety of agricultural products. Therefore, it has greatly promoted the development of international trade in agricultural products. On the one hand, the idea of Belt and Road has strengthened the political and economic ties for the countries along the route; on the other hand, it also provides a good opportunity for the international trade of agricultural products in China. Only by dialectical treatment of the opportunities and choices brought by the idea of initiative for China's agricultural products import and export trade can we judge the situation, change according to the situation, reduce adverse factors, and promote the positive, healthy and stable development of China's agricultural products trade. Seize favorable conditions to improve China's international trade conditions and status.

\subsubsection{Government Attaches Great Importance to Policies in Favour of Relevant Areas}

Agriculture, rural areas, farmers, agriculture, rural areas and farmers have been highly concerned by the Party Central Committee. As a low-value-added necessity, agricultural products must rely on the strong support of government policies to develop healthily. In order to expand the development space in the agricultural field, reduce the burden of farmers' production costs, and mobilize the enthusiasm of farmers to engage in agricultural production as much as possible, China has increased the implementation of preferential policies on subsidies in the field of agricultural production. In order to promote the rapid development of agricultural economy. Secondly, the state finance is also adopting a series of principles and policies, for example, the direction of capital investment is inclined to the field of agricultural science and technology, increasing investment in agricultural science and technology, and using the state government funds to encourage the personnel of scientific research institutions to carry out research on agricultural products. Finally, our country always pursues an independent policy of opening to the outside world, strengthens exchanges and cooperation among countries, and takes the initiative to adopt trade policies such as export subsidies to encourage our agricultural products to go abroad and go to the world. At the same time, our country will also give support to outstanding talents in relevant educational fields, encourage them to study abroad, draw lessons from foreign advanced management technology experience, and gradually establish a perfect agricultural industry standard system and quality supervision system. In order to improve the competitive quality advantage of agricultural products export, expand the scope and quantity of agricultural products export countries.

\subsubsection{Population, Low Labour Costs, Relatively Low Prices for Agricultural Products}

China is one of the most populous countries in the world. Now it is the age of the total number of middle-aged people, and the society has sufficient labor force (including manual and mental workers). The manual laborer is advanta- 
geous to engage in the simple repetitive agricultural work; the mental laborer is advantageous to further study the agricultural science and technology specialized domain, strengthens to the agricultural informationization, the automation domain innovation dynamics. In terms of the relationship between supply and demand in economics, in the human resource market, the supply of labor exceeds the demand, and the price will fall, that is, the cost of labor is relatively low. Products and services by cheap labor are cheaper than in developed countries. For homogeneous products and services, low prices always have an advantage. Therefore, the price advantage brought by our country's population advantage to our country's agricultural products will make the competitive advantage of our country's agricultural products export obvious, and then increase the strength of grain export and improve the status of our country's grain exporter.

\subsection{Competitive Disadvantages of China's Agricultural Trade}

\subsubsection{Export Trade Barriers}

Food hygiene and safety are very important for both developed and developing countries. Therefore, each country will strictly control the imported food and raise the standard. Due to China's backward technology and weak market supervision, the quality of export agricultural products is not high and there are more chemical pesticide residues. Under the non-tariff trade barriers of each country, the export standard of agricultural products in China will be improved, which will affect the type and quantity of agricultural products export in China, and then the foreign trade amount and trade status of agricultural products in China will be at a disadvantage.

\subsubsection{Market Information Is Not Timely, Circulation System Lags Behind}

The trade status of any product depends largely on the price and quality of its products, and of course agricultural products are no exception. Quality and cheap products, its demand and export volume must be large. Therefore, when the technology and quality of agricultural products in China are not comparable to that of other western developed countries, the relevant information of foreign markets is particularly important for our country. By establishing a perfect market information system and ensuring timely market information, we can adjust China's foreign trade of agricultural products according to the latest information of agricultural products in the international market. In addition, the underdeveloped transportation and logistics technology in the international market also hinders the export quantity of agricultural products. The lagging circulation system will reduce the quality of agricultural products in international trade and increase the transportation cost, thus greatly reducing the international competitiveness of agricultural products in China.

\subsubsection{Agricultural Production Technology Backward, Low Degree of Mechanization, Lack of Brand Awareness}

Due to the unique geographical environment and climatic conditions of our 
country, the terrain is mainly mountainous and hilly, the plain area is narrow, and most places are under the influence of monsoon climate, and the drought and flood disasters are frequent. This is undoubtedly a major weakness for agricultural products that are strongly dependent on natural conditions. The narrow plain area is not conducive to the widespread promotion of mechanization, so the output of agricultural products can not be greatly improved. And most of the rural population in China is still on the edge of poverty and has weak economic strength. On the one hand, popularizing mechanization will increase the economic cost of farmers. On the other hand, better operation of related machinery will require improving farmers' technical literacy. Thus will also increase farmers' technical skills training costs. The awareness of brand effect of agricultural products in China is relatively weak, mainly in the form of scattered packaging, with low added value, which leads to the lack of brand advantages in the international market of agricultural products in China. Thus also reduces our country agricultural product foreign trade competition ability to a certain extent.

\section{The Main Ideas and Countermeasures to Further Promote the Healthy Development of China's Agricultural Products Foreign Trade}

In accordance with the general requirements of speeding up the transformation of the mode of development, and taking into account the constraints of the level of economic development and the maturity of technological development, China's agricultural export trade should be promoted step by step selectively and with emphasis.

\subsection{Form a Professional Management Team and Learn from Advanced Management Experience Abroad}

The strength of the country is not only reflected in military strength, at present in a peaceful age, we pay more attention to the cultivation of talent strength. The country flourished and the talent was the basis. Relying on talents to flourish, we should take the road of strengthening the country by talents, perfect the construction of scientific and technological personnel training system in international trade, support scientific and technological managers to enter the grass-roots level to understand the needs of farmers' planting, and strengthen the communication and interaction between technicians and staff. Market personnel engaged in international trade of agricultural products should take the initiative to understand the theory of professional courses such as economics, management, international trade and international marketing, and be familiar with the policies and regulations related to the export of agricultural products and their international trade rules. Moreover, in international trade, the importance of language is self-evident. We should vigorously advocate the study and application of foreign languages and combine them with the theoretical knowledge of international trade. To encourage personnel to consciously understand the development of 
international economy and agricultural products export, pay attention to the use of Internet knowledge, so that personnel have basic professional skills and working ability.

\subsection{Promote Cross-Border e-Commerce of Agricultural Products and Make Good Use of Internet Platforms}

With the strong support of fiscal policy, talent technology and so on, we should deal with the relationship between infrastructure construction and cross-border e-commerce of agricultural products in a timely manner, and government departments should conscientiously do a good job in long-term planning for crossborder international trade of agricultural products, constantly strengthen infrastructure construction, and create a more harmonious and friendly legal environment to build export storage centers for agricultural products, establish information platforms, and realize the effective integration of information on crossborder e-commerce of agricultural products. To actively improve cold chain logistics technology, national departments should also pay attention to standardizing cold chain logistics industry standards, be good at using third-party platforms, outsource third-party logistics companies to carry out domestic and foreign transportation of agricultural products, Adopt international standards to produce agricultural products and build individual, enterprise and state credit system to effectively enhance the quality and safety control effect of agricultural products.

\subsection{Interconnect, Provide Timely Information and Promote Logistics Development}

According to the "Belt and Road" strategy, in the export trade of agricultural products, we can truly realize the interconnection between online and offline, lead the healthy development of international trade of agricultural products in the form of Internet. Improve the level of logistics transportation, at the same time effectively supplement and improve the current agricultural products logistics service system, smoothly promote the successful docking of third-party data platform, government departments actively play their own role in macro-control, Under the premise of multi-party cooperation, the growth rate of international trade of agricultural products is stable, and the speed of logistics operation is greatly improved.

\subsection{Optimizing Target Market Structure to Ensure National Food Security}

According to the advantages of domestic resources, we should improve the quantity and quality of agricultural products exported, give play to the brand effect, take the differentiated demand of each country as the purpose, judge the market orientation properly, and select the target market of import and export accurately. With the change of the situation, timely adjustment countermeasures are made. Gradually expand the agricultural products trade countries and product structure, to prevent the single import and export countries. Establish online 
agricultural products information exchange platform, timely market research, analysis of market demand structure, according to the situation to select import and export countries and product structure.

\section{Conflicts of Interest}

The author declares no conflicts of interest regarding the publication of this paper.

\section{References}

[1] Chen, Z.G. (2011) China Agricultural Products Trade and SPS Measures. Zhejiang University, Hangzhou.

[2] Liu, X.Y. (2006) Impact of Agricultural Trade liberalization on Rural Poverty in China. China Agricultural Publishing House, Beijing.

[3] Wu, H.P. (2016) The Influence of the American Food Strategy on the Development of China's Agricultural Industry. China Social Science Press, Beijing.

[4] Chen, G. (2018) Research on the Transformation and Upgrading of China's Foreign Trade of Agricultural Products Driven by Green Trade. Price Monthly, 1, 60-64.

[5] Chen, J.Y. (2019) Research on the Development Status and Countermeasures of Foreign Trade of Agricultural Products in China. Food Safety Guide, 27, 36.

[6] Hu, D.N. (2020) The Sustainable Development Strategy of China's Agricultural Products Export under the Background of One Belt and One Road. Rural Science and Technology, 11, 38-39.

[7] Yang, Y. (2020) Discussion on the International Trade of Agricultural Products under the Background of One Belt and One Road Construction. South Agricultural Machinery, 11, 38-39. 